\title{
AQUELA QUE VIU MAIS LONGE
}

Lucia Helena GERARDI ${ }^{1}$

Convidada a escrever sobre a Doutora Lívia, prefiro falar sobre a Professora Lívia.

Não vou falar sobre sua exitosa carreira de pesquisadora ou sobre sua importante contribuição a novas linhas de pesquisa em Geografia. Falo a partir das lembranças de uma jovem estudante, de uma colega, de uma amiga e admiradora que com ela conviveu por mais de cinquenta anos.

Era início de 1967. O vestibular para Geografia acontecia. Era específico, com provas escritas e orais perante banca dos professores do departamento. Passei e me mudei para Rio Claro, orgulhosa de poder cursar uma faculdade pública (ainda não era universidade).

A Professora Lívia, chegada em Rio Claro em 1962, a convite do Professor João Días da Silveira, era responsável pela disciplina Didática Especial ou Prática de ensino em Geografia, que pertencia ao Departamento de Educação e que nós veríamos apenas no terceiro ou quarto ano. Assim, de início, quase não tivemos contato.

Mas em 1968, a disciplina foi incorporada pelo Departamento de Geografia e Lívia passou a ter sua sala naquele prédio.

O curso era em tempo integral e os professores estavam presentes no departamento o dia todo, todos os dias. Eu, como bolsista da Fapesp, trabalhava na sala ao lado. Assim, a convivência com a Professora Lívia foi se intensificando e consolidando, mais que uma tutoria, uma amizade.

Em 1970 um grupo de professores e alguns alunos bolsistas, percebendo mudanças paradigmáticas, metodológicas e técnicas na Geografia internacional, começou a discutir essas novidades em reuniões que viriam resultar na Associação de Geografia Teorética. Entre esses, Lívia, sempre atenta às novas tendências.

\footnotetext{
${ }^{1}$ Professora Assistente-doutora (aposentada) da Universidade Estadual Paulista (UNESP), campus de Rio Claro. E-mail: lhogerardi@gmail.com.
} 
Com paciência e maestria ensinava sobre Epistemologia, falava dos filósofos e descortinava horizontes teóricos nunca antes percorridos. E seguiu a vida toda sensível a novos olhares apontando linhas e tendências que viriam a se constituir escola na Geografia Brasileira.

Foi partícipe de primeira hora na estruturação e implantação da pósgraduação e responsável pela disciplina obrigatória Epistemologia e História da Geografia, basilar para a formação do geógrafo.

Era disponível como professora, orientadora e colega. Exigente, precisa, não se furtava a comentar ou criticar os trabalhos e textos, sempre apontando direções. Experimentei esse seu traço quando, em 1972/73, dividi sala com ela, eu como professora recém contratada, desenvolvendo meu doutorado.

Sua dedicação aos alunos foi reconhecida nas tantas vezes em que foi eleita paraninfa ou homenageada pelos formandos. A minha turma teve a honra de ser a primeira a homenageá-la como nossa paraninfa. E ela participou de todas as reuniões de confraternização da turma nestes cinquenta anos de formatura.

Sua energia e entusiasmo eram inspiradores. Manteve-se ativa, orientando, escrevendo, fazendo palestras, participando de eventos científicos até há pouco. Foram mais de seis décadas a serviço do ensino, pesquisa e formação em Geografia.

Seu nome está inscrito na história do pensamento geográfico e hoje, faz parte das referências da disciplina Epistemologia e história da Geografia.

A Ciência Geográfica perdeu uma pesquisadora. O curso de Geografia perdeu uma professora.

Mas eu, perdi uma amiga.

Dela, vinda da pequena Mairinque, pode-se falar como Fernando Pessoa/Alberto Caeiro

"Da minha aldeia vejo quanto da terra se pode ver no Universo...

Por isso a minha aldeia é tão grande como outra terra qualquer

Porque eu sou do tamanho do que vejo

E não do tamanho da minha altura... 
Nas cidades a vida é mais pequena

Que aqui na minha casa no cimo deste outeiro.

Na cidade as grandes casas fecham a vista à chave,

Escondem o horizonte, empurram o nosso olhar para longe

de todo o céu,

Tornam-nos pequenos porque nos tiram o que os nossos olhos nos podem dar,

E tornam-nos pobres porque a nossa única riqueza é ver.”

Viva Lívia! Continue a nos inspirar!

Enviado em 11 de agosto de 2020 